\title{
Seni Decoupage sebagai Sarana Mewujudkan Masyarakat Inklusif
}

\author{
Trisniawati*1, Wahyu Setya Ratri ${ }^{2}$ \\ 1,2Universitas Sarjanawiyata Tamansiswa \\ *e-mail: trisniawati.87@gmail.com¹, agnesbudisantoso@yahoo.com²
}

\begin{abstract}
This study aims to describe how decoupage is a means to realize an inclusive society. This is expected to overcome environmental problems especially inorganic waste management through decoupage. This community service activities was conducted in Jatirejo, Lendah, Kulon Progo, Yogyakarta. Data analyzed in the form of primary data, namely questionnaire on the implementation of activities and the results of interviews. The results of the study show that the community can participate in decoupage activities well. In the evaluation of 45 diffable material present in indicator 1. the material can be received clearly as many as 2 disabilities give a score of 1, 2 disables give a score of 2, 20 disabilities give a score of 3, and 21 disabilities give a score of 4. On the indicator 2. the material is useful for 3 difabel participants gave a score of 1, 3 difabel gave a score of 2, 10 difabel gave a score of 3, and 10 difabel gave a score of 4. In indicator 3. material distributed to participants as much as 1 diffable gave a score of 1, 1 difabel gave a score of 2, 18 difabel give a score of 3 and 25 with disabilities give a score of 4 .
\end{abstract}

Keywords: decoupage, inclusive society, waste management

\begin{abstract}
Abstrak
Kegiatan ini bertujuan untuk mendeskripsikan seni decoupage merupakan sarana untuk mewujudkan masyarakat inklusif. Hal ini diharapkan dapat mengatasi masalah lingkungan terutama pengelolaan sampah anorganik melalui decoupage. Kegiatan pengabdian masyarakat ini dilakukan di Jatirejo, Lendah, Kulon Progo, Yogyakarta. Data dianalisis dalam bentuk data primer, yaitu kuesioner tentang pelaksanaan kegiatan dan hasil wawancara. Hasil kegiatan menunjukkan bahwa masyarakat dapat berpartisipasi dalam kegiatan decoupage dengan baik. Dalam evaluasi 45 bahan difabel yang ada dalam indikator 1. materi tersebut dapat diterima dengan jelas sebanyak 2 difabel memberikan skor 1, 2 difabel memberikan skor 2, 20 difabel memberikan skor 3, dan 21 difabel memberikan skor 4. Pada indikator 2. materi bermanfaat untuk 3 peserta difabel memberi skor 1, 3 difabel memberi skor 2, 10 difabel memberi skor 3, dan 10 difabel memberi skor 4. Di indikator 3. materi dibagikan kepada peserta sebanyak 1 difabel memberi skor 1, 1 difabel memberi skor 2, 18 difabel memberikan skor 3 dan 25 difabel memberikan skor 4.
\end{abstract}

Kata kunci: decoupage, masyarakat inklusif, pengelolaan sampah

\section{PENDAHULUAN}

Permasalahan lingkungan merupakan isu yang tidak bisa dihindarkan pada era revolusi industri 4.0. Saat ini sampah merupakan permasalahan lingkungan yang sangat serius yang di hadapi masyarakat Indonesia pada umumnya. Menurut UU No 18 Tahun 2008 tentang Pengelolaan Sampah, disebutkan sampah adalah sisa kegiatan sehari hari manusia atau proses alam yang berbentuk padat atau semi padat berupa zat organik atau anorganik bersifat dapat terurai atau tidak dapat terurai yang dianggap sudah tidak berguna lagi dan dibuang ke lingkungan (Slamet, 2002). Permasalahan lingkungan merupakan isu yang tidak bisa dihindarkan pada era revolusi industri 4.0. Saat ini sampah merupakan permasalahan lingkungan yang sangat serius yang di hadapi masyarakat Indonesia pada umumnya. Menurut UU No 18 Tahun 2008 tentang Pengelolaan Sampah, disebutkan sampah adalah sisa kegiatan sehari hari manusia atau proses alam yang berbentuk padat atau semi padat berupa zat organik atau anorganik bersifat dapat terurai atau tidak dapat terurai yang dianggap sudah tidak berguna lagi dan dibuang ke lingkungan (Slamet, 2002).

Menurut (Gelbert, Prihanto, \& Suprihatin, 1996), sumber-sumber timbunan sampah adalah sampah dari pemukiman penduduk, sampah dari tempat-tempat umum dan perdagangan, Sampah dari sarana pelayanan masyarakat milik pemerintah, sampah dari industri, dan sampah Pertanian. Pada suatu pemukiman biasanya sampah dihasilkan oleh suatu kluarga yang tinggal 
disuatu bangunan atau asrama. Jenis sampah yang dihasilkan biasanya cendrung organik, seperti sisa makanan atau sampah yang bersifat basah, kering, abu plastik dan lainnya. Sampah dari tempat-tempat umum adalah sampah dari tempat yang dimungkinkan banyaknya orang berkumpul dan melakukan kegiatan. Tempat-tempat tersebut mempunyai potensi yang cukup besar dalam memproduksi sampah termasuk tempat perdagangan seperti pertokoan dan pasar. Jenis sampah yang dihasilkan umumnya berupa sisa-sisa makanan, sampah kering, abu, plastik, kertas, dan kaleng- kaleng serta sampah lainnya. Sampah dari tempat umum yang dimaksud di sini misalnya tempat hiburan umum, pantai, masjid, rumah sakit, bioskop, perkantoran, dan sarana pemerintah lainnya yang menghasilkan sampah kering dan sampah basah. Sampah dari industri dalam pengertian ini termasuk pabrik-pabrik sumber alam perusahaan kayu dan lainlain, kegiatan industri, baik yang termasuk distribusi ataupun proses suatu bahan mentah. Sampah yang dihasilkan dari tempat ini biasanya sampah basah, sampah kering abu, sisa-sisa makanan, sisa bahan bangunan. Sampah pertanian yaitu sampah dihasilkan dari tanaman atau binatang daerah pertanian, misalnya sampah dari kebun, kandang, ladang atau sawah yang dihasilkan berupa bahan makanan pupuk maupun bahan pembasmi serangga tanaman. Menurut (Sari, Lestari, \& Awal, 2018) peran masyarakat dalam pengelolaan sampah diperlukan tidak hanya sebatas dalam membuang sampah di tempat yang seharusnya, namun diharapkan termasuk juga pengolahan sampah yang memberikan manfaat kembali bagi masyarakat itu sendiri.

Jenis sampah yang ada di sekitar kita cukup beraneka ragam, ada yang berupa sampah rumah tangga, sampah industri, sampah pasar, sampah rumah sakit, sampah pertanian, sampah perkebunan, sampah peternakan, sampah institusi/kantor/sekolah, dan sebagainya. Berdasarkan asalnya, sampah padat dapat digolongkan menjadi 2 (dua) yaitu sampah organic dan sampah anorganik. Sampah organik adalah sampah yang dihasilkan dari bahan-bahan hayati yang dapat didegradasi oleh mikroba atau bersifat biodegradable. Sampah ini dengan mudah dapat diuraikan melalui proses alami. Termasuk sampah organik, misalnya sampah dari dapur, sisa-sisa makanan, pembungkus (selain kertas, karet dan plastik), tepung, sayuran, kulit buah, daun dan ranting.

Sampah anorganik adalah sampah yang dihasilkan dari bahan-bahan nonhayati, baik berupa produk sintetik maupun hasil proses teknologi pengolahan bahan tambang. Sampah anorganik dibedakan menjadi sampah logam dan produk-produk olahannya, sampah plastik, sampah kertas, sampah kaca dan keramik, sampah detergen. Sebagian besar anorganik tidak dapat diurai oleh alam/mikroorganisme secara keseluruhan (unbiodegradable). Sementara, sebagian lainnya hanya dapat diuraikan dalam waktu yang lama. Sampah jenis ini pada tingkat rumah tangga misalnya botol plastik, botol gelas, tas plastik, dan kaleng, (Gelbert, Prihanto, \& Suprihatin, 1996).

Jumlah produksi sampah setiap tahun akan meningkat seiring dengan bertambahnya jumlah penduduk. Sampah rumah tangga yang dihasilkan oleh penduduk baik sampak organik maupun anorganik menjadi polemik pelik masalah lingkungan misalnya dibuang sembarangan di berbagai tempat dan efeknya akan merusak lingkungan yang ada di sekitarnya. Menurut (Syafrudin, 2004) salah satu alternatif yang bisa dilakukan adalah melaksanakan program pengelolaan sampah berbasis masyarakat, seperti minimasi limbah dan melaksanakan $5 \mathrm{R}$ (Reuse, Recycling, Recovery, Replacing dan Refilling). Tanggung jawab pengelolaan sampah adalah tanggung jawab bersama baik kelompok difabel ataupun warga masyarakat.

Salah satu pemanfaatan sampah anroganik adalah dengan seni decoupage. Decoupage berasal dari bahasa Perancis découper, artinya memotong, adalah sebuah kerajinan atau bentuk seni yang memerlukan potongan-potongan bahan (biasanya kertas) yang ditempel pada objek dan kemudian dilapisi dengan beberapa lapis pernis atau pelitur (Nurlaila \& Yulastri, 2017). Decoupage adalah seni menghias suatu objek dengan menempelkan kertas tissue ke objek tersebut. Kerajinan decoupage ini sudah populer di mancanegara terutama di Eropa. Tissue yang digunakan memang sedikit berbeda dengan tissue yang kebanyakan dijumpai. Tissue ini disebut Servietten. Decoupage adalah cara menyenangkan dan mudah untuk mendekorasi objek apa saja, termasuk 
benda-benda di rumah mulai dari vas kecil hingga furnitur berukuran besar. Kemungkinannya sangatlah banyak. Namun, untungnya, decoupage bisa dipelajari relatif cepat hanya dengan beberapa langkah. Decoupage saat ini sedang diminati oleh banyak orang, nuansa vintage merupakan nilai khas dari handmade ini.

Menurut (Diana, Irawan, Faridah, \& Anisah, 2018) Kegiatan awal menghias limbah botol dan kaleng dengan teknik decoupage yang akan dilakukan adalah memperkenalkan peralatan dan bahan-bahan yang akan digunakan. Tahapan pembuatan yaitu (1) bersihkan media botol dan kaleng bekas, jika media terasa licin bias diamplas dengan menggunakan kertas amplas, supaya lemnya dapat menempel dengan merata dan sempurna; (2) melakukan pengecatan pada media dengan menggunakan cat acrylic atau cat minyak; (3) setelah dilakukan pengecatan dasar dikeringkan dengan media alat hairdryer atau dijemur langsung di bawah sinar matahari, pengecatan dilakukan lebih dari satu kali dan secara searah; (4) pengecatan kedua dilakukan setelah pengecatan dasar benar-benar kering, (5) saatnya menghias decoupage, pilihlah napkin yang akan digunakan sesuai keinginan dan digunting sesuai dengan motif yang diinginkan, kemudian melumuri seluruh permukaan media dengan lem decoupage hingga rata dengan menggunakan kuas; (6) empelkan napkin tersebut yang sudah dipilih ke atas media sambil digosok-gosok dan ditekan atau ditarik sedikit agar tidak kusut. Pengerjaannya harus lebih berhati-hati karena napkin mudah sobek dan rusak; (7) setelah selesai oleskan lagi lem decoupage ke seluru permukaan napkin, untuk menciptakan kesan coating yang lebih rapi. Ditunggu lebih kurang 15 menit, oleskan lagi lem decoupage ke seluruh permukaan media, untuk menciptakan coating kedua agar tempelan napkin tadi lebih kuat; (8) jika media telah benar-benar kering, baru diberi sentuhan terakhir dengan vernis decoupage, dan dibiarkan sampai benar-benar kering.

Manfaat dari seni decoupage yaitu dapat membantu ibu-ibu rumah tangga untuk menambah penghasilan karena seni ini memiliki nilai seni yang tinggi. Seperti dikemukakan (Nurmaya, Kurnianingsih, Rosini, \& Diana, 2017) bahwa pelatihan decoupage yang diberikan sangat bermanfaat sebagai langkah untuk memperoleh sumber pendapatan lain yang selanjutnya akan berdampak kepada peningkatan ekonomi keluarga. Selama ini hanya sedikit orang saja yang memanfaatkan barang bekas. Padahal, jika kita mau untuk memanfaatkan barang bekas bisa menjadi sumber penghasilan karena barang bekas tersebut bisa kita manfaatkan menjadi barang kerajinan tangan yang memiliki nilai ekonomis. Menurut (Suryani, Aje, \& Tute, 2019) sudah seharusnya untuk menangani limbah ini, kita harus mulai membangun kesadaran masyarakat dari lingkungan yang menghasilkan limbah itu sendiri, yaitu lingkungan rumah tangga. Atas dasar inilah yang mendorong tim dosen PGSD FKIP UST untuk memfasilitasi kepada difabel di desa Jatirejo Lendah Kulonprogo mengadakan pengelolaan sampah anorganik melalui seni decoupage di desa Jatirejo Lendah Kulonprogo.

\section{METODE}

Kegiatan pengabdian ini dilakukan di Desa Jatirejo, Lendah, Kulon Progo dengan jumlah difabel mencapai 30-40 orang. Metode pelaksanaan sendiri mulai dari persiapan seperti koordinasi dengan kader desa, identifikasi permasalahan, penyusunan pendekatan, prosedur dan metode, telaah praktek terbaik, inventarisasi sarana dan prasarana, serta persiapan pelatihan dan pendampingan. Langkah kegiatan yang akan dilakukan untuk mengatasi permasalahan warga difabel dalam pengembangan olahan sampah an-oraganik menjadi produk decoupage sebagai upaya peran serta masyarakat adalah sebagai berikut: 1 . Pendekatan dengan kader pamong desa, 2. Sosialisasi tentang pemilahan dan pengelolaan sampah 3. Pemberdayaan kaum difabel dan pembuatan decoupage melalui media alat rumah tangga, media kaca, pot, dan kaleng.

Pengabdian ini menggunakan metode deskriptif dengan pendekatan kualitatif. Hal ini dilakukan karena peneliti ingin mendeskripsikan secara jelas dan rinci mengenai keterlaksanaan decoupage di desa Jatirejo Lendah Kulonprogo. Penelitian ini dilaksanakan pada bulan September sampai Oktober 2019. Subjek penelitian ini adalah warga masyarakat di desa Jatirejo Lendah Kulonprogo. 
Metode pengumpulan data yang digunakan untuk mendapatkan data adalah metode nontes. Metode ini digunakan untuk mendapatkan data mengenai keterlaksanaan kegiatan decoupage dalam pengelolaan sampah. Adapun metode yang digunakan berupa observasi dan dokumentasi. Analisis data mengacu pada model Miles dan Huberman (Sugiyono, 2010) dilakukan melalui tahap-tahap yaitu: (1) pengambilan data, (2) reduksi data, (3) penyajian data, (4) penarikan simpulan dan verifikasi. Data yang dikumpulkan dalam penelitian ini terkait pemanfaatan decoupage dalam pengelolaan sampah meliputi perencanaan dan keterlaksanaannya, serta produk yang dihasilkan. Menurut (Moleong, 2005), untuk menentukan keabsahan data temuan ada beberapa teknik pemeriksaan meliputi perpanjangan keikutsertaan, ketekunan pengamatan, triangulasi, pengecekan sejawat, kecukupan referensial, kajian kasus negatif, pengecekan anggota, uraian rinci, audit kebergantungan, dan audit kepastian. Pemeriksaan keabsahan temuan dalam penelitian ini menggunakan teknik triangulasi. Teknik triangulasi yang digunakan adalah triangulasi sumber yaitu membandingkan dan mengecek balik derajat kepercayaan suatu informasi yang diperoleh yaitu hasil keterlaksanaan pembelajaran dengan hasil wawancara dan dokumentasi.

\section{HASIL DAN PEMBAHASAN}

Kegiatan yang pertama dilaksanakan adalah koordinasi internal mengenai pembelajaran yang dilaksanakan di prodi PGSD Universitas Sarjanawiyata Tamansiswa terkait mengenai penyusunan jadwal, penyusunan instrument, dan materi kegiatan. Setelah menyusun garis besar pembelajaran kemudian mendiskusikan dengan ketua kelompok difabel di dusun Botokan, Jatirejo, Lendah, Kulonprogo mengenai jadwal pelaksanaan kegiatan penelitian. Kegiatan pembelajaran dilaksanakan pada tanggal Sabtu, 14 September 2019. Kegiatan ini dihadiri oleh 45 difabel di desa Jatirejo Lendah Kulonprogo. Angket yang dibuat untuk evaluasi kegiatan terdiri dari materi, pembicara, serta sarana dan prasarana. Materi terdiri dari butir pernyataan yaitu (1) materi dapat diterima dengan jelas, (2) materi bermanfaat untuk peserta, (3) materi dibagikan kepada peserta, dan (4) ada contoh dari penjelasan materi. Pembicara terdiri dari butir pernyataan yaitu (5) pembicara menyampaikan dengan jelas, (6) penyampaian materi menarik, dan (7) pembicara memberi kesempatan bertanya jawab. Sarana dan prasarana terdiri dari butir pernyataan yaitu (8) kegiatan dilaksanakan tepat waktu, (9) presensi dan fasilitas kegiatan lengkap, (10) konsumsi memadai, dan (11) tim bekerja dengan baik. Teknik pemberian skor terdiri dari skor 1, 2, 3, dan 4. Kriteria pemberian skor yaitu skor 4 jika kondisi sangat sesuai pernyataan, skor 3 jika kondisi sesuai pernyataan, skor 2 jika kondisi kurang sesuai pernyataan, dan skor 1 jika kondisi tidak sesuai pernyataan.

Berikut ini adalah diagram 1. Hasil evalusi materi yang diberikan pada kegiatan praktek decoupage di desa Jatirejo, Lendah, Kulon Progo:

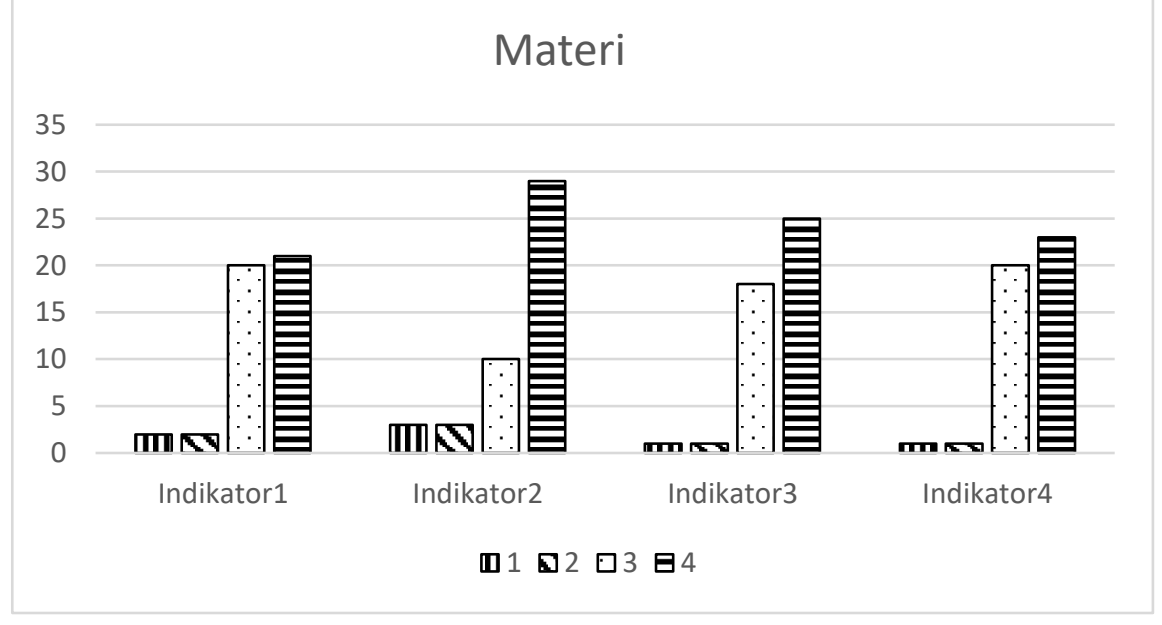


Pada diagram 1 tersebut terlihat bahwa dari 45 difabel yang hadir pada indikator 1. materi dapat diterima dengan jelas sebanyak 2 difabel memberikan skor 1, 2 difabel memberikan skor 2, 20 difabel memberikan skor 3, dan 21 difabel memberikan skor 4. Pada indikator 2. materi bermanfaat untuk peserta sebanyak 3 difabel memberikan skor 1, 3 difabel memberikan skor 2 , 10 difabel memberikan skor 3, dan 10 difabel memberikan skor 4. Pada indikator 3. materi dibagikan kepada peserta sebanyak 1 difabel memberikan skor 1, 1 difabel memberikan skor 2, 18 difabel memberikan skor 3 dan 25 difabel memberikan skor 4. Pada indikator 4. ada contoh dari penjelasan materi sebanyak 1 difabel memberikan skor 1, 1 difabel memberikan skor 2, 20 difabel memberikan skor 3 dan 23 difabel memberikan skor 4. Berikut ini adalah diagram 2. hasil evaluasi pembicara pada kegiatan praktek decoupage di desa Jatirejo, Lendah, Kulon Progo:

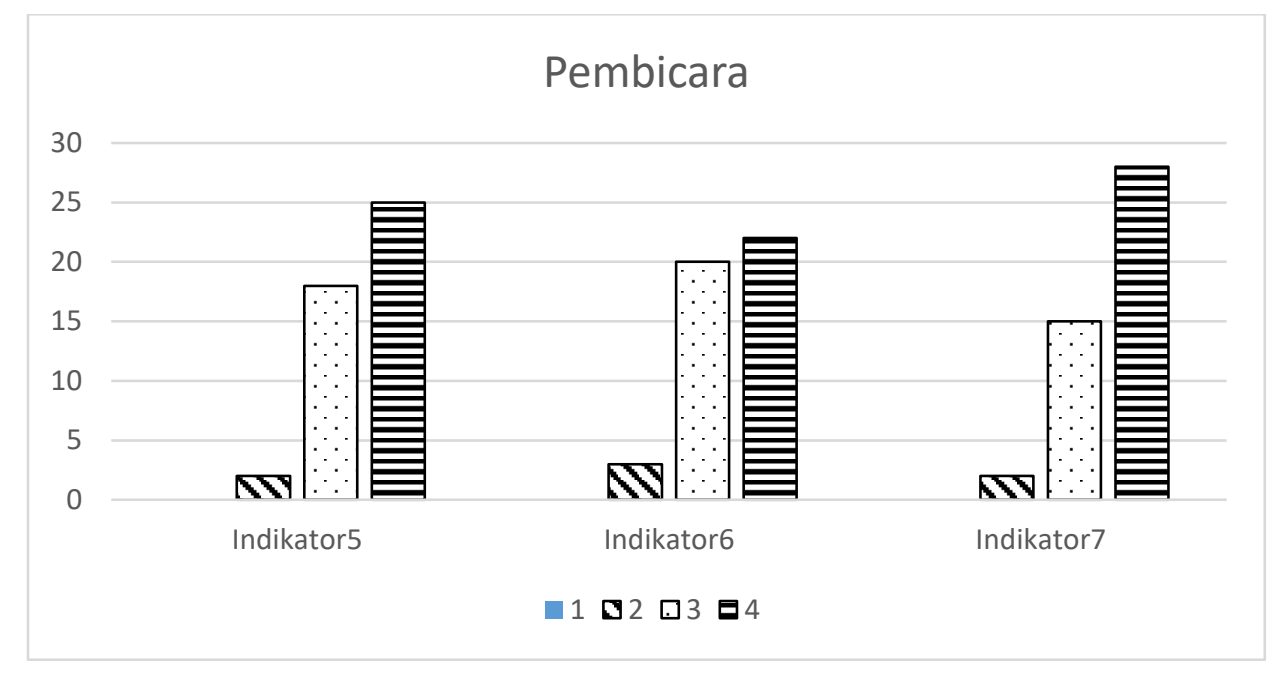

Pada diagram 2 tersebut terlihat bahwa 45 difabel yang hadir pada indikator 5. pembicara menyampaikan dengan jelas sebanyak 1 difabel memberikan skor 2, 18 difabel memberikan skor 3 , dan 25 difabel memberikan skor 4. Pada indikator 6. penyampaian materi menarik sebanyak 3 difabel memberikan skor 2, 20 difabel memberikan skor 3, dan 22 difabel memberikan skor 4 . Pada indikator 7. pembicara memberi kesempatan bertanya jawab sebanyak 2 difabel memberikan skor 2, 15 difabel memberikan skor 3, dan 28 difabel memberikan skor 4.

Berikut ini adalah diagram 3. Hasil evaluasi sarana dan prasarana pada kegiatan praktek decoupage di desa Jatirejo, Lendah, Kulon Progo:

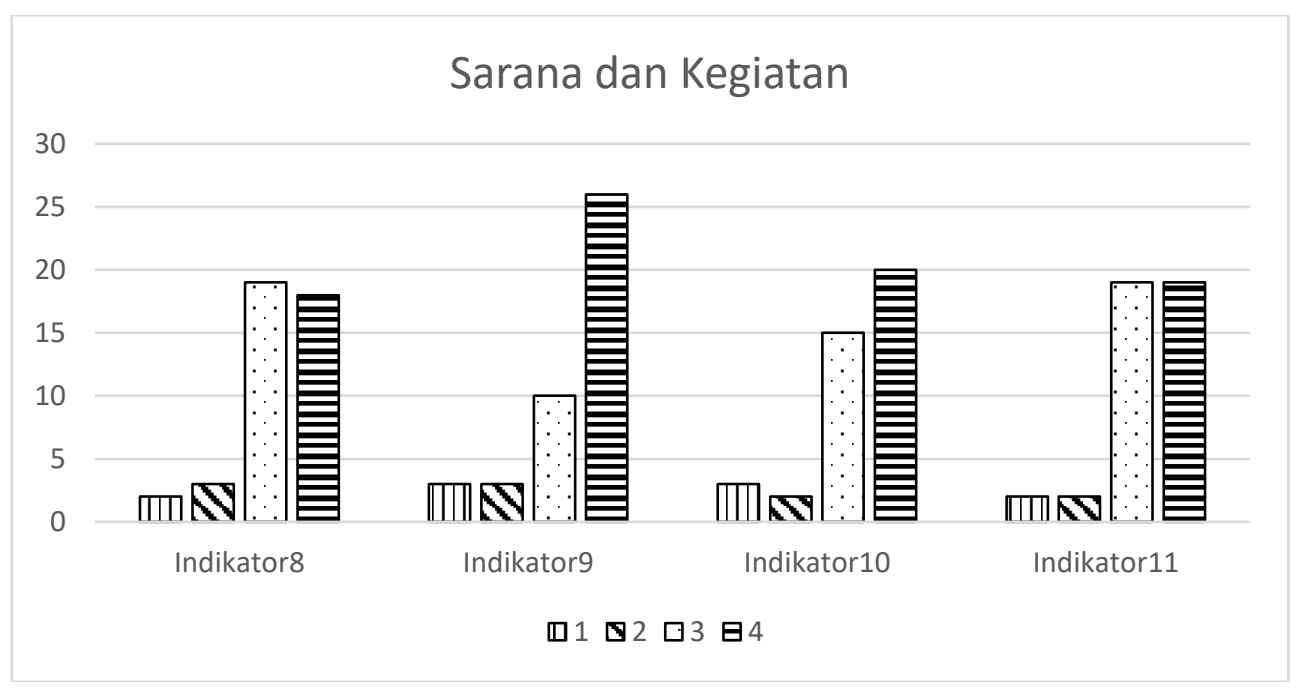


Pada diagram 3 tersebut terlihat bahwa dari 45 difabel yang hadir pada indikator 8 . kegiatan dilaksanakan tepat waktu sebanyak 2 difabel memberikan skor 1, 3 difabel memberikan skor 2, 19 difabel memberikan skor 3, dan 18 difabel memberikan skor 4. Pada indikator 9. presensi dan fasilitas kegiatan lengkap sebanyak 3 difabel memberikan skor 2, 3 difabel memberikan skor 2, 10 difabel memberikan skor 3, dan 26 difabel memberikan skor 4. Pada indikator 10. konsumsi memadai sebanyak 3 difabel memberikan skor 1, 2 difabel memberikan skor 2, 15 difabel memberikan skor 3, dan 20 difabel memberikan skor 4. Pada indikator 11. tim bekerja dengan baik sebanyak 2 difabel memberikan skor 1, 2 difabel memberikan skor 2, 19 difabel memberikan skor 3 dan 19 difabel memberikan skor 4 .

Berikut ini merupakan tahapan-tahapan dari kegiatan pengabdian yang di lakukan di desa Jatirejo, Lendah, Kulon Progo:

1. Koordinasi dengan Kelompok Difabel

Koordinasi dengan kelompok difabel dilaksanakan pada minggu pertama bulan Juli 2019 yaitu pada tanggal 06 Juli 2019. Koordinasi yang dilakukan dengan pengurus kelompok difabel diantaranya adalah mengetahui kegiatan apasaja yang dilaksanakan oleh kelompok difabel kemudian menyesuaikan jadwal kegiatan pengabdian dengan yang dilakukan oleh kelompok difabel. Hasil diskusi pertemuan dengan pengurus kelompok difabel adalah bahwa kelompok difabel secara rutin setiap sebulan sekali mengadakan pertemuan rutin, namun kegiatan yang dilakukan belum optimal hanya sekedar menabung dan memberikan informasi mengenai pemberian bantuan dari desa Jatirejo. Belum ada kegiatan yang produktif yang dilaksanakan oleh kelompok difabel seperti pelatihan dan praktek pembuatan produk. Dalam koordinasi ini juga dilakukan wawancara mengenai pengelolaan sampah anorganik lebih khusus sampah plastik, kaca, atau perabotan rumah tangga yang sudah dipakai. Hasil dari wawancara ini, sampah tersebut hanya dibuang dan dibakar dan belum dimanfaatkan secara optimal.

2. Sosialisasi pemilahan dan pengelolaan sampah

Setelah melaksanakan koordinasi dengan pengurus kelompok difabel maka kegiatan pertama yang dilakukan adalah sosialisasi pemilahan dan pengelolaan sampah. Kegiatan ini dilaksanakan pada minggu ketiga bulan Juli 2019 yaitu 20 Juli 2019. Kegiatan ini dihadiri oleh 46 difabel dan pengurusnya. Dalam kegiatan ini diberikan pemaparan mengenai pemilahan sampah anorganik dan organik, untuk lebih mempermudah kelompok difabel dalam memahami, maka tidak banyak diberikan penjelasan berupa kalimat, namun hanya istilah yang mudah dipahami seperti sampah yang busuk (organik) dan sampah yang tidak busuk (anorganik). Kemudian setelah memberikan istilah yang mudah dimengerti maka diberikan contoh berupa gambar sampah yang busuk dan sampah yang tidak busuk. Setelah ini diberikan pemaparan pengelolaan sampah dalam hal ini sampah anorganik yang bisa diolah menjadi berbagai macam kerajinan termasuk seni decoupage. Kemudian menjelaskan secara garis besar kegiatan praktek yang akan dilaksanakan yaitu praktek decoupage. Setelah itu dijelaskan alat dan bahan yang diperlukan yaitu tissue napkin, cat decoupage, lem decoupage, varnish decoupage, kuas, dan lap. Kemudan pada pertemuan selanjutnya kelompok difabel diminta membawa alat rumah tangga yang sudah tidak dipakai seperti telenan, centong, piring plastik, gelas plastik bekas yang sudah tidak terpakai. Berikut ini adalah dokumentasi kegiatan sosialisasi pemilahan dan pengelolaan sampah pada kelompok difabel: 

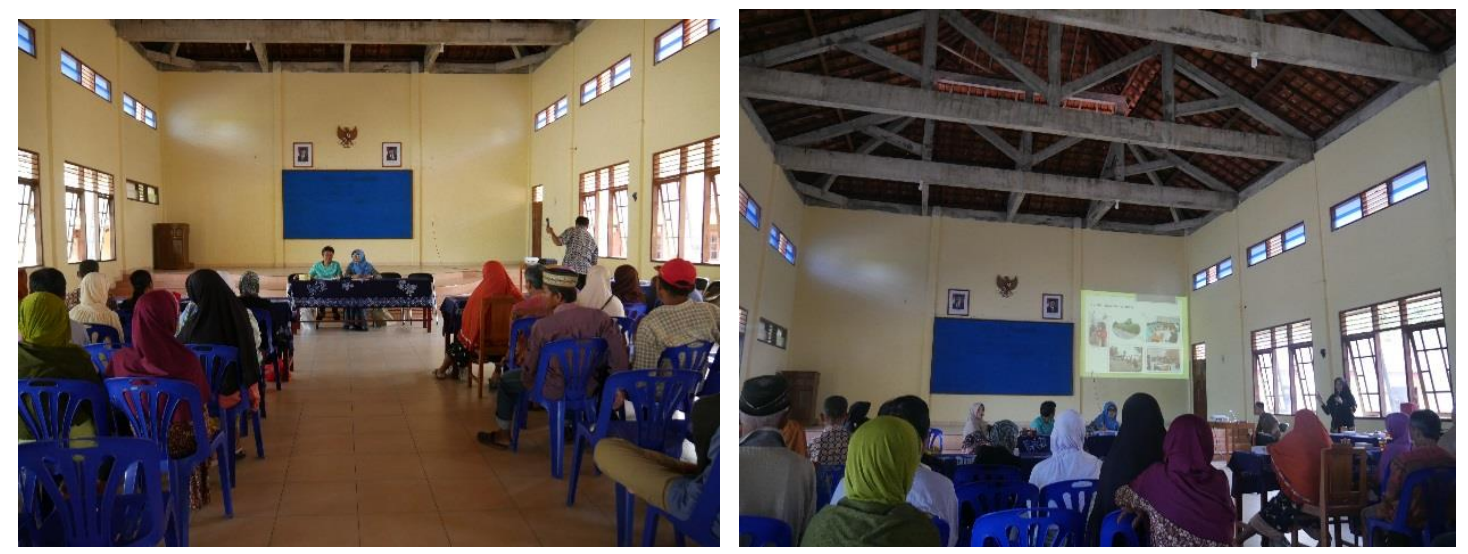

Gambar 1. Pemaparan Pemilahan dan Pengelolaan Sampah
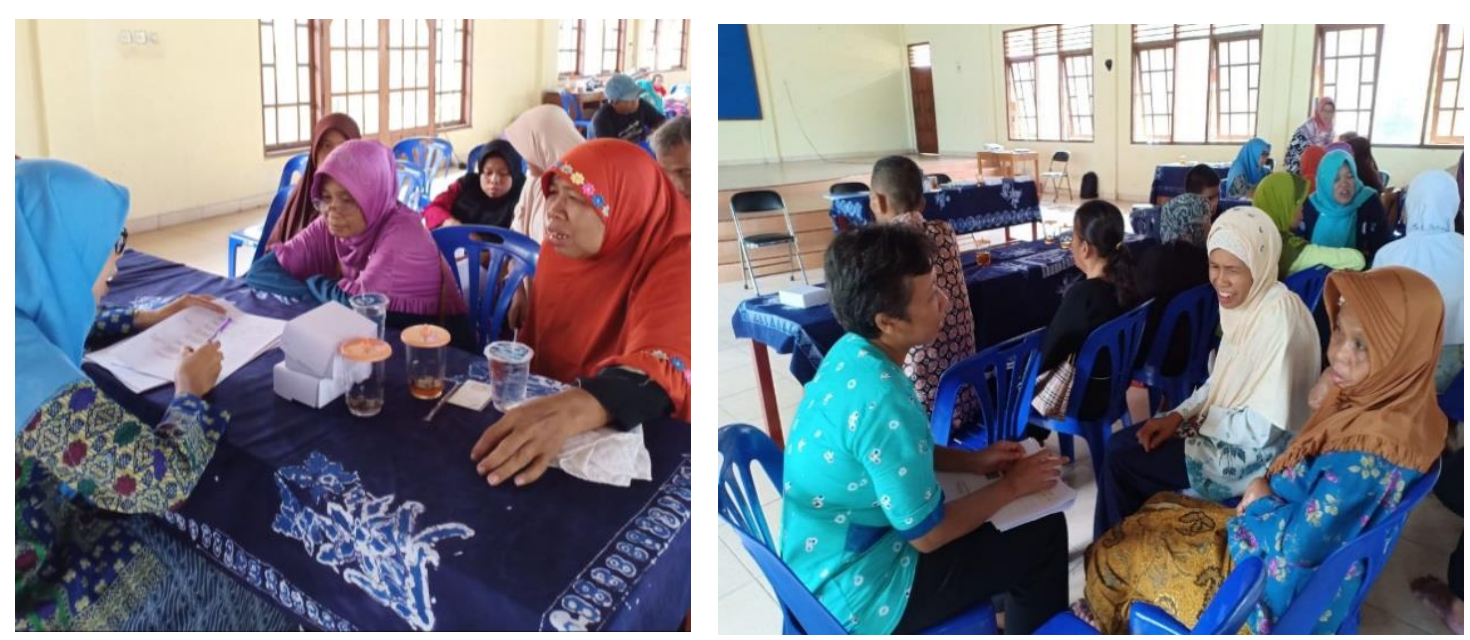

Gambar 2. Wawancara kepada Kelompok Difabel mengenai Pengelolaan Sampah

3. Penyuluhan dan praktek pembuatan decoupage dengan Media Alat Rumah Tangga Kegiatan kedua yang dilakukan adalah penyuluhan dan praktek pembuatan decoupage dengan media alat rumah tangga seperti telenan, centong, piring, gelas plastik. Kegiatan ini dihadiri oleh 47 difabel dan dilaksanakan pada minggu pertama bulan September 2019 yaitu 07 September 2019. Kegiatan dimulai dengan penjelasan langkah-langkah membuat decoupage. Kelompok difabel sudah membawa barang bekas rumah tangga seperti telenan yang sudah rusak, centong kayu yang sudah rusak, kemudian piring plastik, dan gelas plastik yang sudah tidak terpakai. Cara kerja kerajinan decoupage pertama yaitu mengecat media atau benda yang akan kita decoupage menggunakan kuas sponge sebanyak dua kali. Jadi lapisan pertama dibiarkan mengering dulu, kemudian kita cat lagi sampai benar-benar tertutup sempurna. Kedua, gunting napkins atau tissue decoupage mengikuti pola gambar yang akan kita tempel. Cara yang lain bisa menggunakan kuas yang dibasahi air dengan melepas bagian tepi gambar secara perlahan-lahan. Ketiga, napkins yang sudah digunting tadi, atur diatas talenan atau benda yang akan didecoupage sesuai kreatifitas, dikira-kira dulu posisi yang baiknya dimana kemudian tidak lupa letaknya. Selanjutnya tempelkan napkin dengan cara memberi lem diatas talenan sesuai ukuran (diperkirakan) pola yang sudah digunting tadi dan menempelkan napkin secara perlaha-lahan dan usahakan rapat tidak ada lipatan dan gelombang udara. Setelah napkinnya melekat, lem lagi bagian atas napkin karena lemnya transparan jadi gambar dan warnanya tetap akan nampak. Biarkan sampai kering, jika sudah kering dan yakin tidak ada lagi yang ingin di tambahkan kemudian vernish sebagai tahap akhir. Selain agar decoupage tidak mudah pudar, juga memberi efek mengkilap. Setelah memberikan contoh kemudian kelompk difabel praktek sesuai dengan barang yang sudah mereka bawa, Untuk alat dan bahan decoupage sudah disediakan dari pemateri yaitu berupa berbagai macam tissue napkin, cat decoupage, lem decoupage, varnish decoupage, kuas, dan 
lap. Berikut ini adalah dokumentasi kegiatan praktek decoupage dengan media alat rumah tangga:

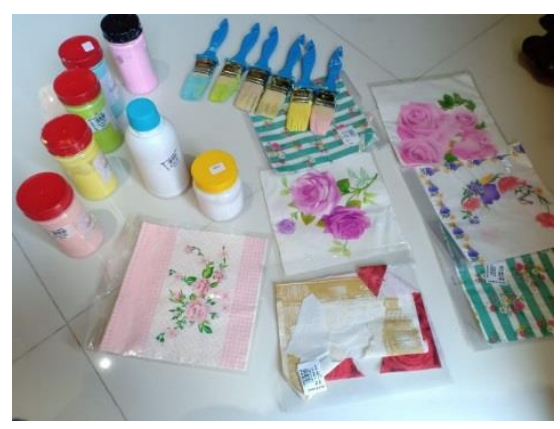

Gambar 3. Alat dan Bahan Decoupage
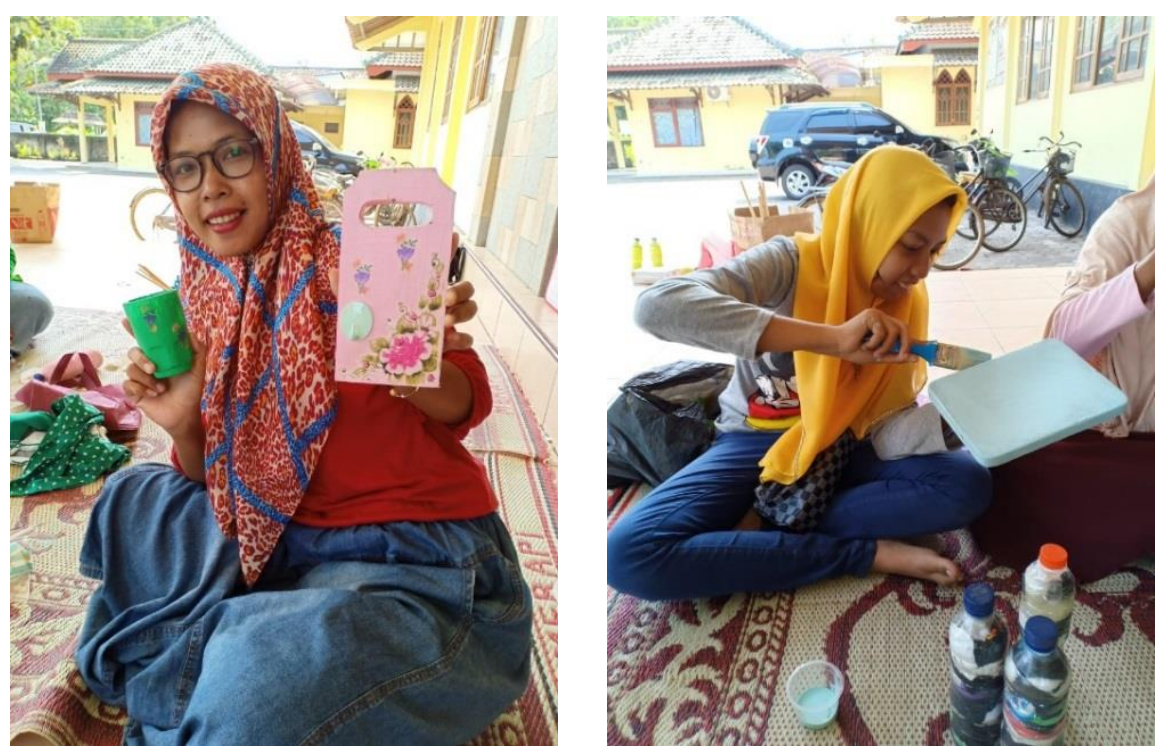

Gambar 4. Praktek Decoupage dengan Media Alat Rumah Tangga

Setelah mengikuti kegiatan kedua ini kelompok difabel desa Jatirejo, Lendah, Kulonproo sangat senang dan merasa kegiatan yang dilakukan sangat bermanfaat dan produk yang dibuat lebih cantik. Ada salah satu warga yang bahkan menanyakan dimana dapat membeli alat dan bahan dan berapa biaya yang dibutuhkan untuk membeli alat dan bahan decoupage. Kemudian dipertemuan selanjutnya kelompok difabel dibawa botol kaca bekas, pot yang yang tidak dipakai atau toples makanan bekas lebaran.

4. Penyuluhan dan praktek pembuatan decoupage dengan Media Kaca, Pot, dan Kaleng Kegiatan ketiga yang dilakukan adalah penyuluhan dan praktek pembuatan decoupage dengan media kaca, pot, dan kaleng seperti contohnya botol kaca bekas, pot yang sudah rusak, toples makanan. Kegiatan ini dihadiri oleh 45 difabel dan dilaksanakan pada minggu kedua bulan September 2019 yaitu 14 September 2019. Kegiatan dimulai dengan penjelasan langkah-langkah membuat decoupage. Kelompok difabel sudah membawa barang bekas rumah tangga seperti botol kecap, botol minyak goreng, botol sirup, pot yang tidak terpakai, dan toples yang sudah tidak terpakai. Cara kerja kerajinan decoupage pertama yaitu mengecat media atau benda yang akan kita decoupage menggunakan kuas sponge sebanyak dua kali. Jadi lapisan pertama dibiarkan mengering dulu, kemudian kita cat lagi sampai benar-benar tertutup sempurna. Kedua, gunting napkins atau tissue decoupage mengikuti pola gambar yang akan kita tempel. Cara yang lain bisa menggunakan kuas yang dibasahi air dengan melepas bagian tepi gambar secara perlahan-lahan. Ketiga, napkins yang sudah digunting tadi, atur diatas talenan atau benda yang akan didecoupage sesuai kreatifitas, dikira-kira dulu posisi yang baiknya dimana kemudian tidak lupa letaknya. Selanjutnya tempelkan napkin 
dengan cara memberi lem diatas botol, pot, atau toples sesuai ukuran (diperkirakan) pola yang sudah digunting tadi dan menempelkan napkin secara perlaha-lahan dan usahakan rapat tidak ada lipatan dan gelombang udara. Setelah napkinnya melekat, lem lagi bagian atas napkin karena lemnya transparan jadi gambar dan warnanya tetap akan nampak. Biarkan sampai kering, jika sudah kering dan yakin tidak ada lagi yang ingin di tambahkan kemudian vernish sebagai tahap akhir. Selain agar decoupage tidak mudah pudar, juga memberi efek mengkilap.

Setelah memberikan contoh kemudian kelompk difabel praktek sesuai dengan barang yang sudah mereka bawa, Untuk alat dan bahan decoupage sudah disediakan dari pemateri yaitu berupa berbagai macam tissue napkin, cat decoupage, lem decoupage, varnish decoupage, kuas, dan lap. Berikut ini adalah dokumentasi kegiatan praktek decoupage dengan media kaca, pot, dan kaleng:
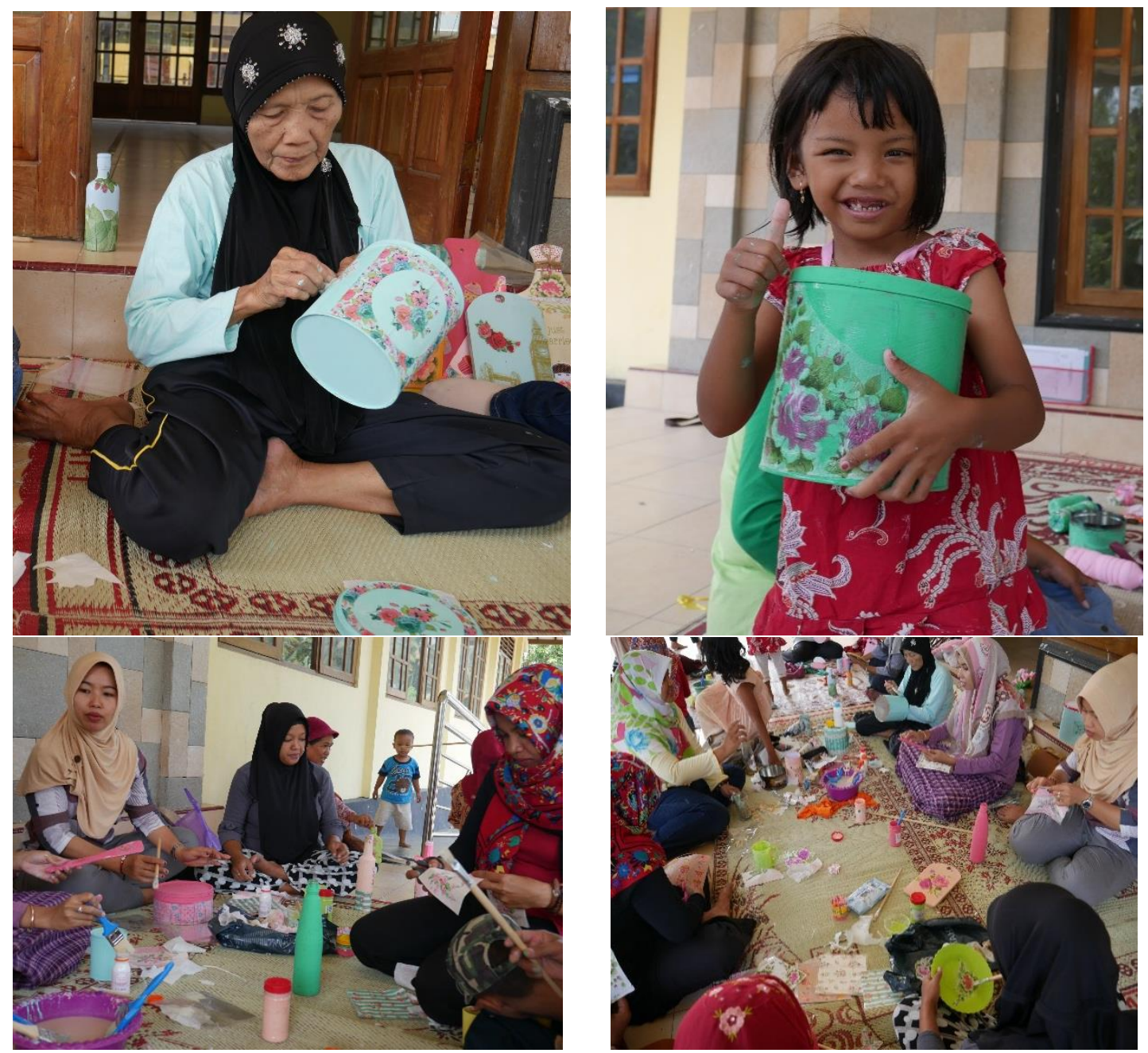

Gambar 5. Praktek Decoupage dengan Media Kaca, Pot, dan Kaleng

Pada kegiatan ini difabel maupun warga masyarakat bekerjasama sebagai warga untuk menjaga lingkungan dari polusi sampah melalui decoupage sehingga dapat mewujudkan masyarakat inklusif yaitu masyarakat yang mampu menerima berbagai bentuk keberagaman dan keberbedaan serta mengakomodasinya ke dalam berbagai tatanan maupun infrastruktur yang ada di masyarakat. Hal mengenai proses peningkatan kesadaran masyarakat untuk ikut berpartisipasi dalam hal melestarikan lingkungan hidup dapat dilakukan melalui kegiatan kelompok. Kegiatan ini sebagai media komunikasi untuk merumuskan apa penyebab terjadinya kerusakan lingkungan hidup dan apa pula solusinya (Karim, 2018). 


\section{KESIMPULAN}

Berdasarkan uraian kegiatan pengabdian masyarakat di desa Jatirejo, Lendah Kulon Progo dapat disimpulkan:

1. Hasil kegiatan menunjukkan bahwa warga masyarakat desa Jatirejo, Lendah, Kulon Progo dapat mengikuti kegiatan pengelolaan sampah an organik melalui decoupage dengan baik.

2. Warga masyarakat antusisas dan senang mengikuti kegiatan penyuluhan dan dapat memiliki wawasan mengenai pemilahan sampah dan pengelolaan sampah anorganik melalui decoupage.

3. Pelaksanaan pengabdian dilaksanakan pada hari Sabtu, 14 September 2019. Pada kegiatan ini difabel maupun warga masyarakat bekerjasama sebagai warga untuk menjaga lingkungan dari polusi sampah melalui decoupage sehingga dapat mewujudkan masyarakat inklusif.

4. Berdasarkan hasil angket diperoleh hasil yang baik pada skor maksimal 4 di setiap indikator

\section{UCAPAN TERIMA KASIH}

Penulis mengucapkan terima kasih kepada LP3M Universitas Sarjanawiyata Tamansiswa yang telah memberi dukungan financial terhadap pengabdian ini

\section{DAFTAR PUSTAKA}

Diana, D., Irawan, Y., Faridah, F., \& Anisah, Y. (2018). Pelatihan Pemanfaatan Limbah Rumah Tangga Dengan Teknik Decoupage Di Desa Meunasah Mesjid Punteut Kec. Blang Mangat Kota Lhokseumawe. Jurnal Vokasi - Politeknik Negeri Lhokseumawe, 2(1). https://doi.org/10.30811/vokasi.v2i1.673

Gelbert, M; Prihanto, D; Suprihatin, A. (1996). Konsep Pendidikan Lingkungan Hidup dan "Wall Chart", Buku Panduan Pendidikan Lingkungan Hidup. Malang: PPPGT/VEDC.

Karim, A. (2018). Mengembangkan Kesadaran Melestarikan Lingkungan Hidup Berbasis Humanisme Pendidikan Agama. Edukasia: Jurnal Penelitian Pendidikan Islam, 12(2), 309. https://doi.org/10.21043/edukasia.v12i2.2780

Moleong, M. . (2005). Metodologi Penelitian Kualitatif. Bandung: PT Remaja Rosdakarya.

Nurlaila, N., \& Yulastri, L. (2017). Pemberdayaan Ibu-Ibu Pkk Kelurahan Rawamangun Dalam Pelatihan Pembuatan Decoupage Dari Tissue Berbasis Industri Kreatif. Sarwahita, 14(02), 151-155. https://doi.org/10.21009/sarwahita.142.10

Nurmaya, Kurnianingsih, I., Rosini, \& Diana, N. E. (2017). Ibm Pelatihan Decoupage Dan ECommerce Untuk Meningkatkan Ekonomi Ibu Rumah Tangga. Prosiding Seminar Hasil Pengabdian Kepada Masyarakat (SNP2M) 2017, 160-165. Retrieved from http://snp2m2017.poliupg.ac.id/prosiding-snp2m2017/

Sari, M., Lestari, S. U., \& Awal, R. (2018). Peningkatan Ketrampilan Mahasiswa Dalam Pengelolaan Sampah Organik Untuk Mewujudkan Green Campus Di Universitas Lancang Kuning. Dinamisia: Jurnal Pengabdian Kepada Masyarakat, 2(2), 193-196. https://doi.org/10.31849/dinamisia.v2i2.1392

Slamet, J. S. (2002). Kesehatan Lingkungan. Yogya: Gadjah Mada University Press.

Sugiyono. (2010). Metode Penelitian Pendidikan: Pendekatan Kuantitatif, dan R\&D. Bandung: Alfabeta.

Suryani, L., Aje, A. U., \& Tute, K. j. (2019). Pkm Pelatihan Kelompok Anak Cinta Lingkungan Kabupaten Ende Dalam Pegelolaan Limbah Organik Dan Anorganik Berbasis 3R Untuk Mengeskalasi Nilai Ekonomis Barang Sebagai Bekal Wirausaha Mandiri. Dinamisia : Jurnal Pengabdian Kepada Masyarakat, 3(2), 244-251. https://doi.org/10.31849/dinamisia.v3i2.3679. 
Syafrudin. (2004). Pengelolaan Sampah Berbasis Masyarakat. Prosiding Diskusi Interaktif Pengelolaan Sampah Terpadu, Program Magister Ilmu Lingkungan Universitas Diponegoro. https://doi.org/10.2307/40248107\&ISSUEID=10.2307 